\title{
Linking farmers to markets in Kenya: The evolving KACE model
}

\section{Adrian Mukhebi James Kundu}

Kenya Agricultural Commodity Exchange Limited

Brick Court 2nd Floor

Mpaka Road

Westlands

P.O. Box 59142-00200

Nairobi

Kenya

<amukhebi@kacekenya.co.ke>

<wekesakundu@yahoo.com>

\begin{abstract}
The Kenya Agricultural Commodity Exchange Limited (KACE) was incorporated in 1992 but formally launched in 1997 to address the challenges facing farmers in Kenya, especially poor smallholder farmers, in accessing input and output markets. A commercial for-profit model was chosen in order to charge clients modest fees for services rendered and raise revenue to sustain the services in the long term. The KACE model has evolved through various stages over time, with KACE developing, testing and experimenting with various platforms to link smallholder farmers to more remunerative markets. This article describes the various platforms, the challenges that were experienced and how they were addressed at each stage in the evolution. Chronologically, these platforms consisted of a physical trading floor, market information points (MIP), information and communication technology (ICT)-based platforms (short messaging service - SMS, interactive voice response service - IVRS, Internet based website and electronic database and radio), market resource centres (MRC), and a market call centre (MCC). Thus, the challenge experienced by KACE has been to find the right mix or portfolio of appropriate and affordable technology platforms, with complementary human skill and capacity, to efficiently manage the technologies, as well as the revenue flows, towards increased technical and financial sustainability. Despite the challenges, the KACE model continues to evolve and function, with a social entrepreneurial spirit of determination, to provide a solution to the social problem of poor smallholder farmers in Kenya, and God and technology willing, in the rest of Africa. The ICT platforms are being upgraded to improve technical and financial performance and efficiency, and the MRC staff are being trained to improve their capacity to generate and manage revenue efficiently.
\end{abstract}

Key words: information and communication services (ICTs); market access; market information services; small farmers.

Subjects: economy and rural development; tools and methods.

\section{Résumé}

Relier les agriculteurs au marché : évolution du modèle développé par KACE au Kenya

Le Kenya Agricultural Commodity Exchange (KACE) a été créé en 1992, mais lancé formellement en 1997 pour apporter une réponse aux difficultés auxquelles sont confrontés les agriculteurs du Kenya, surtout les plus pauvres, pour accéder aux marchés des intrants et des produits agricoles. Afin d'assurer la durabilité sur le long terme des services qu'il rend, KACE a opté pour un modèle commercial lui permettant de faire payer aux clients de faibles droits pour bénéficier des services rendus. Le modèle de KACE a évolué au cours du temps, KACE ayant développé, testé et expérimenté différentes platesformes pour relier les producteurs aux marchés les plus rémunérateurs. Le présent article décrit - pour les différents stades de l'évolution de KACE - ces différentes plates-formes, les défis auxquels elles ont eu à faire face et les solutions trouvées pour les relever. Dans l'ordre chronologique, ces plates-formes ont été une bourse de marchandise, des Market Information Points (MIP), des plates-formes basées sur les technologies de l'information et de la communication ou TIC (SMS, services interactifs de réponse vocale, site Internet et
Reprints: A. Mukhebi

doi: 10.1684/agr.2014.0710
To cite this article: Mukhebi A, Kundu J, 2014. Linking farmers to markets in Kenya: The evolving KACE model. Cah Agric 23: 282-7. doi : 10.1684/agr.2014.0710 
base de données en ligne et émissions de radio), des Market Resource Centers (MRC) et un centre d'appel de marché. Le défi auquel KACE a eu à faire face a ainsi été de trouver la bonne combinaison entre les plates-formes technologiques disponibles et pertinentes et les ressources humaines nécessaires pour les faire fonctionner, tout en générant le revenu nécessaire à une plus grande durabilité technique et financière. En dépit des difficultés rencontrées, le modèle de KACE continue d'évoluer et KACE travaille avec la détermination que lui confère son esprit entrepreneurial pour trouver une solution au problème social des agriculteurs pauvres du Kenya et, la technologie le permettant, du reste de l'Afrique. KACE est en train d'élargir la base d'utilisateurs de ses plates-formes techniques, ce qui devrait améliorer leurs performances techniques et financières. Il forme aussi le personnel des MRC afin d'améliorer sa capacité à générer des revenus et à les gérer efficacement.

Mots clés : accès au marché ; petit agriculteur ; service d'information marchés ; technologies de l'information et de la communication.

Thèmes : économie et développement rural ; méthodes et outils.

$\mathrm{F}$ armers' access to agricultural input and output markets in Kenya is still a major challenge, especially for smallholder farmers, despite rapid advances in information and communication technologies (ICTs) in recent years. Agricultural markets are characterized by long chains of transaction between the farmer and the consumer, with high transaction costs. Farmers often lament about exploitation by middlemen in the market place.

\section{The KACE model and its evolution}

The Kenya Agricultural Commodity Exchange Limited (KACE) (www. kacekenya.co.ke) was incorporated in 1992, but was formally launched in 1997, to address the challenges facing farmers in Kenya, especially poor smallholder farmers, in accessing input and output markets. A commercial for-profit model was chosen in order to charge clients modest fees for services rendered and raise revenue to sustain the services in the long term.

The KACE model has evolved through various stages over time, with KACE developing, testing and experimenting with various platforms to link smallholder farmers to more remunerative markets. The following is a description of the various platforms and the challenges that were experienced and how they were addressed at each stage in the evolution.

\section{The physical trading floor}

Initially, KACE set up a trading floor with physical trading boards in Nairobi. Farmers were expected to come and place offers to sell produce or place bids to buy inputs on the trading boards, and buyers were expected to come to the trading floor and bid to buy the offers or offer to supply the bids placed on the boards. Modest fees were charged for offer or bid placements on the trading floor (i.e. US\$ 5.88 per offer or bid). A negotiable commission of between 0.5 and $5 \%$ of the value of a transaction was charged on successful transactions. This model operated from 1993 to 1995 . During this time, a number of challenges were experienced. The quantities of produce offered by farmers were too small to be of much interest to large-volume buyers. In addition, the quality of produce was highly variable, often below the standards required by buyers. Furthermore, the trading floor in Nairobi was too far from most farmers across the country. As a result of these challenges, the trading volume was too low to sustain operations and this led to the closure of the trading floor in Nairobi.

\section{The devolution to market information points}

In 1995-1996, KACE decided to decentralize the activities of the trading floor from Nairobi to rural market centres, closer to farmers, and introduced an information service targeting the smallholder farmers. With financial support from the Centre for Agricultural and Rural Development (CTA) of the European Union and the African, Caribbean and Pacific (ACP) group of countries based in Wageningen, the Netherlands, KACE established Market Information Points (MIPs) in Machakos (Eastern Kenya), Eldoret in Rift Valley, and Chwele and Bungoma in western Kenya. MIPs were information kiosks set up in rural markets where farmers went to sell produce and buy inputs. In addition, commodity traders went to the markets to buy produce from farmers.

A MIP was staffed by a Manager, Assistant Manager, and a support staff member. It was equipped with ICTs, such as PC computers, mobile phones, and Internet connectivity. The task of a MIP was twofold. First, to collect market prices on commodities traded in the market in which it was located, and submit this information to KACE headquarters in Nairobi. KACE would receive the price information, verify its accuracy, prepare a summary of the information from all MIPs, and send the summary back to each MIP via email. The MIPs would then print and 
display the price information on bulletin boards for farmers and traders who had free access. This information was intended to enhance the bargaining power of farmers for better prices with traders. The second MIP task was to operate a trading floor at the MIP; sellers (farmers) would place offers and buyers (traders) would place bids on a trading board for a small fee (US\$ 1.18 per offer or bid), and MIP staff would broker the transactions at a commission, negotiable between 0.5 and $5 \%$ of the value of a transaction. The challenge with this MIP model was that most clients who visited the MIP to view offers and bids as well as price information actually transacted business outside the MIP (Tollens, 2006). Thus, the amount of revenue generated by the MIP remained low.

\section{The ICT revolution and the MIS}

During this same period, there was a revolution in mobile telephony, with the arrival of the mobile phone in Kenya. KACE sought to harness the power of the mobile phone as a platform for the transmission of market price information; from MIPs to KACE headquarters in Nairobi, and from KACE directly to users using the short messaging service (SMS) and the interactive voice response service (IVRS). The Rockefeller Foundation and the ACDI/VOCA (Agricultural Cooperative Development International and Volunteers in Overseas Cooperative Assistance), through agricultural projects they were implementing in Kenya, provided financial support to KACE to develop these SMS and IVRS platforms. In addition, the establishment of five additional MIPs was supported by the projects: at Ugunja and Kisumu in Nyanza, Mumias and Cheptais in Western Province, and Kitale in the Rift Valley province in Kenya.

The SMS and IVRS services were developed on a revenue share basis with mobile phone service providers (MPSPs); users paid a premium per SMS and IVRS, and KACE was to be paid a small proportion, often less than $20 \%$ of the premium rate. The majority of fees collected (60\%) went to the MPSPs, and the balance of $40 \%$ was to be shared between KACE and third party ICT firms contracted by the
MPSPs to provide SMS \& IVRS services to downstream service providers, such as KACE.

The SMS platform has been more successful than the IVRS; there is an average of 30,000 SMS messages per month, sometimes as high as 50,000 during crop harvest times. On the other hand, IVRS hits have not been more than 1,500 per month even during peak season times. The premium per IVRS call is higher (at about US\$ 0.35) compared to US\$ 0.08 per SMS. However, there have been challenges in receiving the revenue share due to KACE from the third party ICT firms. Besides, KACE has no access to, nor is it able to verify, the actual volume of SMS messages or IVRS calls reported by the third party ICT firms.

Two Internet-based platforms were also developed: the KACE website (www.kacekenya.co.ke) and an electronic database termed the Regional Commodity Trade and Information System (RECOTIS). KACE disseminates updated market price information through the website and RECOTIS. About 1,000 user email addresses are in the electronic database. Updated market price information is sent daily to recipients in the database as email messages in an Excel worksheet attachment. The information is also posted on the website, with access through subscription. Information is sent on 42 crop and livestock commodities. A time series database of monthly average prices is also available at the KACE website on subscription. Subscribed recipients of daily updated market prices pay KACE a subscription fee of US\$ 65 for six months or US\$ 125 for 12 months. However, of the 1,000 recipients, only $30 \%$ are subscribed, the rest being uncharged students in agricultural colleges/universities. Time series data is available at negotiated rates.

Most farmers, except the few organized in groups, associations or cooperatives, have no Internet connectivity and are therefore not able to receive information through the KACE website or the RECOTIS.

\section{Market resource centres and the franchise model}

It became apparent to KACE that there were more services demanded at the
MIPs beyond market price information. Farmers were demanding shortterm storage for their commodities not sold at the end of a market day, so as to avoid selling them at throw-away prices at the end of the market day. Traders demanded quality testing services such as weighing of produce or testing for moisture content and transportation. Other clients wanted mobile phone airtime, access to Internet, etc. To meet these demands, the range of services provided at a MIP was expanded beyond market information to include provision of any relevant (agriculturalbased) demand-driven services on commission. As a result, the name MIP was changed to Market Resource Centre (MRC).

The MRC platform presented KACE with a management burden. To address this, KACE decided to introduce a franchise mode in 2006. In this model, MRCs would transform into autonomous companies but networked with KACE through a franchise agreement. They would develop and offer services on commission for financial sustainability. They would pay KACE a franchise fee (of 2\%) based on the volume of their sales revenues. Seven MRCs were franchised in 20062007: Bungoma, Machakos, Mumias, Eldoret, Kitale, Cheptais, and Kimilili. Franchised MRCs were expected to be financially self-sustaining after two years of operation, while providing affordable services targeted at the smallholder farmers and small and medium enterprises (SMEs). KACE oversees the activities of the franchised MRCs to ensure that they develop services that are standardized, affordable, and appropriate to the needs of poor smallholder farmers. KACE provided capacity enhancement business training and technical assistance to the franchisees, and also arranged guaranteed start-up phase credit through a micro-finance institution. The aim of the training was to equip franchisees with the necessary knowledge and skills to provide services to smallholder farmers and SMEs on sound commercial business lines and enhance the chances for their financial success.

Following the 2007-2008 post-election violence in Kenya, in which over 1,500 people were killed as a result of a disputed election, KACE MRCs 
were badly affected; most were vandalized and equipment and commodity stocks stolen, and a considerable farmer clientele was lost due to farmer displacement. Only Bungoma, Chwele, Kitale, Eldoret, and Machakos survived the turmoil. Of these franchised MRCs, two are financially self-sustaining, one is almost selfsustaining, and two are still struggling.

\section{The radio programme and market call centre}

To assist franchised MRCs in improving and broadening the range of their market linkage services, KACE developed a virtual trading floor through the use of radio and market call centre platforms.

The initial radio platform to be established was with the West FM Radio Station in Bungoma Town in western Kenya, in a region where most franchised MRCs were located. A radio programme branded Soko Hewani (the Supermarket On Air) was introduced in 2006. During a 15-minute programme, a KACE presenter would broadcast selected offers and bids, and ask listeners to call provided mobile phone numbers of MRCs closest to them for more information on the offers or bids, or provide new offers or bids.

However, the West FM had a limited range with coverage of an area with only $100-\mathrm{km}$ radius from Bungoma Town. KACE decided that a radio platform with national coverage would be more effective in linking offers from production surplus to bids in production deficit regions across the country. As a result, the Soko Hewani programme was transferred to the Kenya Broadcasting Corporation radio (KBC) in Nairobi, which is the national radio station, in 2011.

To complement and promote the national Soko Hewani radio programme, KACE established a Market Call Centre (MCC) with a premium phone number (for which users paid an extra charge beyond a normal call charge), whereby radio listeners would call for information about offers and bids and market linkage services. The MCC calls were on a revenue share basis, as previously explained for the SMS/IVRS services.
Whereas the volume of calls to the MCC was substantial, especially during the Soko Hewani broadcast periods (e.g. as many as 2,000 calls within the 15-minute programme), there were several challenges experienced. First, the MCC would break down or crash from time to time. The capacity installed was not sufficient to handle a deluge of calls at once. Second, there was a damaging malfunction in charging premium for the MCC calls at one time; whereas the agreed charge was US\$ 1.18 per call regardless of the length of time, callers were charged this rate per minute! This chased away many clients from the service. Attempts were made to correct the error, but the damage had already been done. Besides, the cost of hosting a 15-minute Soko Hewani programme on KBC was high, at US\$ 706. To make matters worse, there was a challenge in receiving revenues generated from the calls from the third party ICT service provider. Due to these challenges, KACE suspended the MCC and Soko Hewani for reformulation of the platforms for technical efficiency and revenue generation. With technical assistance from the International Trade Centre (ITC), since August 2013, these platforms have been reformulated and tested ready for a re-launch in October 2013. In the reformulated platforms, client payments go directly to KACE, through mobile phone money transfer systems, such as the Safaricom's popular and well-known M-Pesa system.

\section{Some perspectives and lessons learned}

The structure of agriculture in Kenya is dominated by smallholder farmers who produce and offer small quantities of highly varied quality produce. It is difficult to link such farmers to better markets through formal or orthodox centralized commodity exchange, which requires offers/bids of large-volume produce of standard quality grades. Whereas a decentralized exchange closer to farmers offers an alternative, this requires complementation with effective and affordable ICT-based platforms for wider coverage.
Although mobile phone-based platforms offer appropriate and affordable ICT platforms for linking smallholder farmers to better markets, they benefit MPSPs more than the downstream service providers such as KACE that actually use them to provide services to farmers. MPSPs take the lion's share of the premiums charged. It would help if the downstream service providers had more direct revenue sharing contractual arrangements with MPSPs, rather than having to go through third party ICT firms contracted to the MPSPs, or better still, if the service providers could receive client payments for the ICT services directly. By providing reliable and timely market information and market linkage services targeted at smallholder farmers, KACE is expected to improve the efficiency of agricultural markets, and enhance the bargaining power of smallholder farmers in the market place for better prices, resulting in higher farm-gate prices and farm incomes. With higher incomes, farmers would afford to invest in modern technologies to increase productivity. With higher productivity at better prices, smallholder farmers would further increase their incomes, thus creating wealth and escaping the vicious cycle of poverty that they currently find themselves trapped in. Besides market price information, it was the experience of KACE that market linkage mechanisms, which enable the farmer to actually sell his/her produce or purchase needed inputs on time and at competitive prices, are key to making markets work better for the poor smallholder farmer. In a study of MIP users, Asaba et al. (2005) found that farmers in rural areas were willing and able to pay for additional marketing services beyond market information for more effective linkages to input and output markets. They demanded services such as commodity grading, storage, transportation, short-term credit (for example to hire transport to market), document preparation, mobile phone services, and other e-services such as e-mail. However, there were no local entrepreneurs with the knowledge and capacity to develop and deliver the services in the remote rural areas where most farmers live. A further lesson for KACE is that scaling out the MIP model, whereby MIPs are owned 
and managed by KACE in order to provide an expanded range of services demanded by farmers, would create unsustainable financial and management burdens upon KACE, hence the adoption of the franchise model.

In a review of KACE in 2006, Tollens notes that most MIS in Africa limit themselves to market price information. This is the essence of a MIS However, KACE also has a commodity exchange service through matching offers and bids, which are prominently displayed on blackboards at MIPs and disseminated via SMS and the Internet. This is a substantial institutional innovation, unheard of until now, and could really be a major institutional breakthrough in the reform of agricultural markets in Africa (Tollens, 2006). However, KACE has given priority to the development of platforms (MCC and national Soko Hewani) for up-scaling the matching of offers and bids in a way that would generate revenue for financial sustainability.

Meuleman (2007), in a study of the impact of the KACE market information system, concluded that the proportion of farmers and traders that say their incomes have increased and their bargaining positions have improved is very high (75\% farmers and $60 \%$ commodity traders). Furthermore, Meuleman concluded that it was clear that during the years in which the KACE has been operational, market integration improved for two commodities studied (i.e. maize and beans). This study also highlighted the challenges faced by KACE then, including poor infrastructure that imposes high transport costs to markets, high costs of mobile phone calls and SMS, and small quantities of produce of varying quality offered. However, in Kenya, as in other countries in Africa where mobile telephony has expanded rapidly in recent years, access to a phone has increased and the cost of a call and SMS has decreased. The boom of ICTs renders MISs more efficient but also less necessary as it allows farmers and other market players to get more easily the information they need by calling relatives and friends. For a MIS such as KACE, the answer to this has been to provide additional services beyond just market price data. KACE has tried to do this by providing: i) broader information about the market (the interactive radio program, Soko Hewani); ii) data on offers and bids (MCC); and iii) additional services to facilitate the connection between sellers and buyers (the MRCs).

Other lessons based on KACE include the following:

- first, market price information per $s e$ is necessary but not a sufficient condition for smallholder farmers to actually access better input and output markets; complementary services such as storage, bulking into reasonable volumes and other value-addition to access large-volume buyers, transportation, and trade finance (e.g. for transport) are also needed;

- second, ICTs have a critical role to play in enabling farmers in remote rural areas to access market information and other services. However, ICT costs must be sufficiently low to be affordable to smallholder farmers;

- third, to be financially self-sustaining, market information services must cover large areas, connecting commodity surplus and deficit areas.

\section{Summary and conclusions}

KACE was established to address the challenges facing farmers in Kenya, especially poor smallholder farmers, in accessing input and output markets. A decentralized user-fee model ${ }^{1}$ was chosen in order to charge clients modest fees for services rendered and raise revenue to sustain the services in the long term. The model has evolved over time, developing, testing and experimenting with various ICT-based platforms to link poor smallholder farmers to more remunerative markets. Chronologically, these platforms were a physical

\footnotetext{
${ }^{1}$ However, not all users of KACE services pay fees. For instance, those who receive price information broadcasted on radio do not pay any fees, thus the service is a public good. In addition, KACE does not charge student recipients for its information through RECOTIS, although this will change in the reformulated platforms such that any user will have to send payment by the mobile phone money transfer platform in order to access KACE offers, bids, and price information.
}

trading floor in Nairobi, rural market information points (MIPs), information and communication technology (ICT)-based platforms (short messaging service - SMS, interactive voice response service - IVRS, Internetbased website and electronic database and radio), market resource centres (MRC), and a market call centre (MCC)

There were technical and financial challenges that cropped up at each stage that limited the generation of revenue for financial sustainability. A central trading floor in Nairobi was too far removed from farmers in rural Kenya. Although farmers and traders visited MIPs to access market information, they transacted most of their deals outside of the system, denying KACE much needed revenue. The SMS function applied had limited capacity to transmit a large volume of data; several SMS messages were required to disseminate price data, which was not only cumbersome but increased expense to the user. The IVRS is relatively too expensive for smallholder farmers; the capacity of the MCC installed proved inadequate for the volume of calls at peak times. The key financial challenges were the small proportional share of user SMS, IVRS, and MCC calls that ICT firms were willing to give to $\mathrm{KACE}$, plus the inability of the ICT firms to pay KACE, even the little that was due to KACE. In addition, MIPs and MRCs lacked financial capacity and discipline to generate and manage their finances well enough to pay KACE some agency or franchise fees. Political instability that occurred in 20072008 negatively impacted MRC operations to the extent that some closed and only a few survived.

Thus, the challenge experienced by KACE has been to find the right mix or portfolio of appropriate and affordable technology platforms, with complementary human skill and capacity, to efficiently manage the technologies as well as the revenue flows towards increased technical and financial sustainability.

Despite the challenges, the KACE model continues to evolve and function, with a social entrepreneurial spirit of determination, to provide a solution to the social problem of poor smallholder farmers in Kenya, and God and technology willing, in the 
rest of Africa. KACE has been operating without reliance on any external funding since May 2012. However, since August 2013, with technical assistance from the ITC, the ICT platforms have been reformulated to improve technical and financial performance and efficiency, and the MRC staff have been retrained in order to improve their capacity to generate and manage revenue efficiently. The reformulated platforms were relaunched in October 2013.

\section{References}

Asaba JF, Musewe R, Kimani M, Day R, Nkonu M, Mukhebi AW, et al., 2005. Bridging the information and knowledge gap between urban and rural communities through knowledge centers: case studies from East Africa. Unpublished manuscript. Nairobi (Kenya): CABI.

Meuleman L, 2007. Impact Study of the market information system of KACE in Kenya. M.Sc. Thesis, Catholic University of Leuven, Faculty of Bioscience Engineering (Belgium).

Tollens EF, 2006. Market information systems in sub-Sahara Africa: challenges and opportunities. Poster paper presented at the International Association of Agricultural Economists Conference, Gold Coast, Australia, August 12-18, 2006. http://www.researchgate.net 